\title{
Preslaughter diet management in sheep and goats: effects on physiological responses and microbial loads on skin and carcass
}

\author{
Govind Kannan, Venkat R Gutta, Jung Hoon Lee*, Brou Kouakou, Will R Getz and George W McCommon
}

\begin{abstract}
Sixteen crossbred buck goats (Kiko $\times$ Spanish; BW = $32.8 \mathrm{~kg}$ ) and wether sheep (Dorset $\times$ Suffolk; BW= $39.9 \mathrm{~kg}$ ) were used to determine the effect of preslaughter diet and feed deprivation time (FDT) on physiological responses and microbial loads on skin and carcasses. Experimental animals were fed either a concentrate (CD) or a hay diet (HD) for $4 \mathrm{~d}$ and then deprived of feed for either 12-h or 24-h before slaughter. Blood samples were collected for plasma cortisol and blood metabolite analyses. Longisimus muscle (LM) pH was measured. Skin and carcass swabs were obtained to assess microbial loads. Plasma creatine kinase activity (863.9 and $571.7 \pm 95.21 \mathrm{IU}$ ) and non-esterified fatty acid concentrations $(1,056.1$ and $589.8 \pm 105.01 \mathrm{mEq} / \mathrm{L})$ were different $(P<0.05)$ between sheep and goats. Species and diet treatments had significant effects on the ultimate $\mathrm{pH}$ of LM. Pre-holding total coliform (TCC) and aerobic plate counts (APC) of skin were significantly different between species. Goats had lower $(P<0.05)$ TCC (2.1 vs. $3.0 \log _{10} \mathrm{CFU} / \mathrm{cm}^{2}$ ) and APC (8.2 vs. $\left.8.5 \log _{10} \mathrm{CFU} / \mathrm{cm}^{2}\right)$ counts in the skin compared to sheep. Preslaughter skin $E$. coli counts and TCC were different $(P<0.05)$ between species. Goats had lower $(P<0.05)$ counts of $E$. coli (2.2 vs. $\left.2.9 \log _{10} \mathrm{CFU} / \mathrm{cm}^{2}\right)$ and TCC (2.3 vs. $\left.3.0 \log _{10} \mathrm{CFU} / \mathrm{cm}^{2}\right)$ in the skin compared with those in sheep. Diet, species, and FDT had no effect $(P>0.05)$ on E. coli and TCC in carcass swab samples. The APC of carcass swab samples were only affected $(P<0.05)$ by the FDT. The results indicated that preslaughter dietary management had no significant changes on hormone and blood metabolite concentrations and sheep might be more prone for fecal contamination than goats in the holding pens at abattoir.
\end{abstract}

Keywords: E. coli contamination diet, Goats, Physiology, Sheep

\section{Background}

The hide and viscera of animals entering the abattoir are potential sources of contamination of carcasses with pathogenic bacteria [1]. The hide of the live animal becomes contaminated with pathogenic and non-pathogenic microorganisms from a wide range of sources such as feces, soil, water, and vegetation [2]. Animals can spread the contaminants to other animals during preslaughter transport and holding, directly via physical contact with one another or with the contaminated floor [3]. Fecal shedding of bacteria can be controlled by manipulating the preslaughter diet [4] and feed deprivation time [5] in ruminants.

Preslaughter dietary manipulation may not only affect the micro flora in gastrointestinal tracts in ruminants,

\footnotetext{
* Correspondence: leej@fvsu.edu

Agricultural Research Station, Fort Valley State University, 1005 State University Drive, Fort Valley, GA 31030, USA
}

but may also influence the variables related to meat quality and animal welfare [6,7]. Feeding grain diets can change the rumen and intestinal microbial populations [8]. Overfeeding cattle with grain has been shown to cause a $2 \log$ scale increase in total coliform counts [9].

Stress and dehydration resulting from preslaughter management methods can adversely affect production variables such as live and carcass weights as well as meat quality [10]. A switch to hay feeding from a concentrate diet is likely to influence carcass weights, although Stanton and Schultz [11] indicated that such a diet change did not have a dramatic impact on carcass characteristics and final body weights in cattle. However, Kannan et al. [12] reported that $18 \mathrm{~h}$ of feed deprivation resulted in a $10 \%$ live weight shrinkage in goats. Earlier studies also showed that fasting sheep for $24 \mathrm{~h}$ resulted in about $7 \%$ live weight loss due to reduction in gut contents $[13,14]$. Feed deprivation is one 
of the preslaughter stress factors that may be responsible for depletion of muscle glycogen prior to slaughter [15]. Preslaughter depletion of muscle glycogen may result in an abnormally high $\mathrm{pH}$ of meat, which may have adverse effects on meat quality such as dark cutters [16] and poor shelf life due to microbial spoilage [17].

Blood hormone and metabolites in ruminants are also influenced by feed deprivation. Plasma cortisol concentration, a good indicator of welfare status during the preslaughter period in food animals [18], increases in sheep [19] and goats [12] due to feed deprivation. Feed deprivation also alters plasma glucose $[20,21]$, urea nitrogen $[10,12]$, and non-esterified fatty acid [22,23]. Kannan et al. [24] reported an increase in creatine kinase activity in the circulation during preslaughter feed deprivation in goats.

The objectives of this study were, therefore, to estimate the efficacy of preslaughter diet (concentrate vs roughage) and feed deprivation time (12 vs. $24 \mathrm{~h}$ ) on E. coli and other enteric bacterial population on skin and carcass, as well as to determine the effects on blood hormone and metabolites in sheep and goats.

\section{Methods}

Animal feeding and feed deprivation treatments

Experimental procedures involving animals were conducted with approval of the Fort Valley State University (FVSU) Institutional Animal Care and Use Committee. Animals were obtained from the Georgia Small Ruminant Research and Extension Center at (FVSU). Sixteen crossbred wether sheep (Dorset x Suffolk; BW $=39.9 \pm 0.88 \mathrm{~kg}$ ) and buck goats (Kiko x Spanish; BW $=32.8 \pm 0.91 \mathrm{~kg}$ ) grazed on winter pea and rye grass dominant forages were assigned in a completely randomized design to a feeding trial consisting of two dietary treatments: primarily corn based concentrate (Table 1) and Bermuda grass hay diets. Each treatment was replicated in two pens with either four sheep or goats per pen. Each pen of four experimental

Table 1 Ingredient composition of concentrate diet ${ }^{1,2}$ fed to sheep and goats

\begin{tabular}{ll}
\hline Ingredient & Composition,\% \\
\hline Cottonseed hull & 14.0 \\
Ground corn & 67.8 \\
Soybean meal & 13.6 \\
Poultry fat & 2.73 \\
Trace minerals ${ }^{3}$ & 0.5 \\
Vitamin premixed & 0.5 \\
Dicalcium phosphate & 0.9
\end{tabular}

${ }^{1}$ Predicted digestible Energy $(\mathrm{DE})=4.0 \mathrm{Mcal} / \mathrm{kg}$.

${ }^{2}$ Crude protein $=12.9 \%$.

${ }^{3}$ Composition: $\mathrm{NaCl}, 45$ to $50 \%$; $\mathrm{Ca} 9.0$ to $10.8 \%$; $\mathrm{P},>4.5 \%$; $\mathrm{Mg},>1.5 \%$; $\mathrm{K},>0.9 \%$; $\mathrm{S},>0.3 \% ; \mathrm{Zn},>1.55 \%$; and I, >180 ppm; $\mathrm{Fe},>2,000$ ppm; $\mathrm{Mn},>4,000$ ppm; $\mathrm{Se},>60 \mathrm{ppm}$; vitamin $\mathrm{A},>2,200,000 \mathrm{IU}$; vitamin $\mathrm{D}_{3},>165,000 \mathrm{IU}$; and vitamin $\mathrm{E},>6,600 \mathrm{IU} / \mathrm{kg}$. animals was fed twice a day either a concentrate (CD) or hay diet (HD) with ad libitum access to water for 4 days. At the end of the 4-d feeding trial, half of animals from each pen $(n=16)$ were randomly selected and transported to the university slaughter and processing facility. Each animal was weighed and then assigned to a pen in the holding area according to the original pen numbers in order to maintain the same social group. This group of animals was deprived of feed for a 24-h period with continuous access to water. Other half of animals ( $n=8 /$ pen) were assigned to deprive of feed for a $12 \mathrm{~h}$ period according to previously descried in the $24 \mathrm{~h}$ feed deprivation. Both feed deprivation time (FDT) groups were processed on the same day such that harvest occurred within the same time frame for both group.

\section{Animal behavior}

Behavior of each animal was monitored for a 90-min period before slaughter. The weather conditions were identical on the experimental days. Minimum temperatures ranged from 5 to $7^{\circ} \mathrm{C}$ and maximum temperatures ranged from 18 to $20^{\circ} \mathrm{C}$. Standing, moving, agonistic (ramming, jumping, horning, and head butting) lying and drinking behaviors were recorded. Behavioral observations were made every minute using the scan sampling method in each pen (from pen 1 to 8) [25]. At each monitoring period, the number of animals performing each behavior was recorded. Animals were slaughtered in a predetermined order and rotated among pens to avoid confounding of effects.

\section{Blood sampling and analysis}

Blood samples were collected from each animal at the beginning of the feeding trial (pretrial) and prior to slaughter. Blood samples were collected by trained personnel via jugular venipuncture into $10 \mathrm{~mL}$ Vacutainer tubes containing $81 \mu \mathrm{L}$ of $15 \%$ EDTA solution and immediately placed on ice. All efforts were made not to agitate the animals during sampling. Plasma was separated by centrifugation at $1,000 \times \mathrm{g}$ for $30 \mathrm{~min}$ in a Sorvall Superspeed model 5RC2-B automatic refrigerated centrifuge (Ivan Sorvall Inc., Newton, CT) and stored in a $10-\mathrm{mL}$ vial at $-20^{\circ} \mathrm{C}$ for determination of plasma cortisol, glucose, creatine kinase (CK), urea nitrogen (PUN), and non-esterified fatty acid (NEFA) concentrations.

Plasma cortisol concentrations were determined using a Coat-A-Count radioimmunoassay (RIA) kit (Diagnostic Product Corp., Los Angeles, CA) as described by Kannan et al. [12]. Blood glucose and PUN concentrations and CK activity were analyzed using an IDEXX VetTest ${ }^{\bullet}$ instrument (IDEXX Laboratories Inc., Westbrook, ME). The plasma sample was delivered into a pipette tip and dispensed onto each metabolite testing slide. As the sample was absorbed and filtered through the layers of the slides, 
color changes occurred due to biochemical reactions. The color and intensity were measured by an optical system. Plasma NEFA concentrations were analyzed using a commercially available kit (Wako Chemicals, Richmond, VA) as described by Kannan et al. [24]. The assay was performed using acetyl CoA synthetase/acetyl-CoA oxidase method (NEFA C Code No. 994-75409 E). The absorbance values were determined using a Shimadzu ${ }^{\oplus}$ (Model UV-2401 PC) UV-VIS spectrophotometer (Shimadzu Scientific Instruments, Inc., Columbia, MD).

\section{Carcass yield and muscle $\mathrm{pH}$}

Animals were weighed prior to slaughter and then processed at the FVSU slaughter and meat processing facility. After final carcass wash, hot carcass weights were recorded. Dressed carcasses were stored at $2^{\circ} \mathrm{C}$ for $24 \mathrm{~h}$ before fabrication. After $24 \mathrm{~h}$ cooling, cold carcass weights were also recorded. Dressing percent of each carcass was reported as carcass yield. Muscle $\mathrm{pH}$ was recorded at 0(immediately after skinning) and 24-h postmortem using a portable $\mathrm{pH}$ meter (Fisher Scientific, Pittsburgh, PA) with a penetrating probe (Pakton ${ }^{\bullet}$ Model OKPH1000N, Fisher Scientific). The probe was inserted directly into the longissimus muscle of each carcass to measure $\mathrm{pH}$.

\section{Microbial counts}

Sterile sponges, hydrated with $10 \mathrm{~mL}$ of buffered peptone water (BioPro Enviro-Sponge Bags, International BioProducts, Redmond, WA) with disposable sterile paper templates $(5 \mathrm{~cm} \times 5 \mathrm{~cm})$ were used for collection of skin and carcass swab samples. The swab sampling procedure for skin was adopted from Kannan et al. [26]. Samples were obtained from each animal at the beginning of the feeding trial and prior to slaughter by swabbing the hind leg within the $25 \mathrm{~cm}^{2}$ template area with five vertical wipes and five horizontal wipes. Carcass swab sampling was followed by the USDA procedure used for genetic E. coli testing [27] as modified by Kannan et al. [26]. The modification was the smaller sampling area and fewer wipes to suit the smaller size of goat carcasses instead of the $10 \mathrm{~cm} \times 10 \mathrm{~cm}$ template recommended by the USDA. Swab samples were collected from each carcass after skinning and evisceration, but before washing by swabbing three different anatomical locations (flank, brisket, leg) within the $25-\mathrm{cm}^{2}$ template area for a total sampling area of $75 \mathrm{~cm}^{2}$. The swab samples were placed in sterilized sponge bags, transported on ice, and stored under refrigeration until analysis.

After swabbing, the sponges were transferred into sterilized stomacher bags and $90-\mathrm{mL}$ of $0.1 \%$ sterile buffered peptone water (Difco Laboratories, Detroit, MI) was added to each bag. The contents of the bag were pummeled in a stomacher (Seward Model 400, Tekmar Co. Cincinnati, $\mathrm{OH}$ ) for $1 \mathrm{~min}$. Serial dilutions were prepared with $0.1 \%$ sterile buffered peptone water. The $3 \mathrm{M}^{\mathrm{TM}}$ Petrifilm plate techniques were used to enumerate microbial loads on skin and carcass samples as recommended by the manufacturer [28]. Appropriate sample dilutions were inoculated on Petrifilm plates $\left(3 \mathrm{M}^{\mathrm{m} \mathrm{m}}\right.$ Microbiology Products, St. Paul, MN) to determine E. coli and total coliform (3M ${ }^{\mathrm{mm}}$ Petrifilm $^{\text {TM }}$ E. coli/coliform Counts Plates) counts (TCC), and aerobic plate $\left(3 \mathrm{M}^{\mathrm{TM}}\right.$ Petrifilm ${ }^{\mathrm{TM}}$ aerobic Count Plates) counts (APC) as prescribed by the supplier. Colonies were counted after 24-h incubation in a Fisher Isotemp incubator (Fisher Scientific, Pittsburgh, PA) at $35^{\circ} \mathrm{C}$ for $E$. coli and total coliform counts, and after 48-h incubation for aerobic plate counts. Bacterial counts of skin and carcass samples were converted to $\log _{10} \mathrm{CFU} / \mathrm{cm}^{2}$ values.

\section{Statistical analysis}

The body weight (BW) data were analyzed as a Completely Randomized Design (CRD) with repeated measures using the PROC MIXED procedure of SAS (SAS institute Inc., Cary, NC), with individual animal as experimental unit. The effects of species, diet, FDT, and their interactions were considered to be fixed effects. Behavior data were analyzed as a CRD with $2 \times 2$ factorial treatment arrangement using the PROC MIXED procedures of SAS, with animal as a random effect and species, diet, and their interactions considered as fixed effects. Blood data were also analyzed as a CRD with $2 \times 2 \times 2$ factorial treatment using the PROC MIXED procedures of SAS, with animal considered to be a random effect. The effects of species, diet, FDT, and their interactions were considered to be fixed, with pretrial concentrations as covariate. Carcass yield, muscle $\mathrm{pH}$, and microbial data were also analyzed as a CRD with $2 \times 2 \times 2$ factorial treatment using the PROC MIXED procedures of the SAS, with animals considered to be a random effect and species, diet, and feed deprivation considered to be fixed effects.

The following statistical models were used to analyze 1) body weight data; 2) behavior data (standing, moving, agonistic, lying and drinking); 3) blood data (plasma cortisol, glucose, creatine kinase, plasma urea nitrogen, and non-esterified fatty acids); and 4) carcass yield, muscle $\mathrm{pH}$ and microbial data (E. coli, Enterobacteriaceae, total coliform, and aerobic plate counts):

$$
\begin{aligned}
& \mathrm{Y}_{\mathrm{ijklm}}=\mu+\mathrm{S}_{\mathrm{i}}+\mathrm{D}_{\mathrm{j}}+\mathrm{F}_{\mathrm{k}}+\mathrm{T}_{\mathrm{l}}+\mathrm{SD}_{\mathrm{ij}}+\mathrm{SF}_{\mathrm{ik}}+\mathrm{ST}_{\mathrm{il}} \\
& +\mathrm{DF}_{\mathrm{jk}}+\mathrm{DT}_{\mathrm{jl}}+\mathrm{FT}_{\mathrm{kl}}++\mathrm{SDF}_{\mathrm{ijk}}+\mathrm{SDT}_{\mathrm{ijl}} \\
& +\mathrm{SFT}_{\mathrm{ikl}}+\mathrm{DFT}_{\mathrm{jkl}}+\mathrm{SDFT}_{\mathrm{ijkl}}+\mathrm{e}_{\mathrm{ijklm}} \\
& Y_{i j k}=\mu+S_{i}+D_{j}+S D_{i j}+e_{i j k} \\
& \mathrm{Y}_{\mathrm{ijklm}}=\mu+\mathrm{S}_{\mathrm{i}}+\mathrm{D}_{\mathrm{j}}+\mathrm{SD}_{\mathrm{ij}}+\mathrm{DF}_{\mathrm{jk}}+\mathrm{SF}_{\mathrm{ik}} \\
& +\mathrm{SDF}_{\mathrm{ijk}}+\mathrm{B}_{\mathrm{l}}+\mathrm{e}_{\mathrm{ijklm}} \\
& \mathrm{Y}_{\mathrm{ijkl}}=\mu+\mathrm{S}_{\mathrm{i}}+\mathrm{D}_{\mathrm{j}}+\mathrm{F}_{\mathrm{k}}+\mathrm{SD}_{\mathrm{ij}}+\mathrm{DF}_{\mathrm{jk}}+\mathrm{SF}_{\mathrm{ik}} \\
& +\mathrm{SDF}_{\mathrm{ijk}}+\mathrm{e}_{\mathrm{ijkl}}
\end{aligned}
$$


Where $\mathrm{Y}_{\mathrm{ijkl}}$ or $\mathrm{Y}_{\mathrm{ijklm}}=$ dependent variables, $\mu=$ overall means, $S_{i}=$ species, $D_{j}=$ diet, $F_{k}=$ feed deprivation, $T_{l}=$ body weights (prior to diet, feed deprivation, and slaughter) as repeated measures, $B_{1}=$ pretrial concentrations of plasma cortisol, glucose, creatine kinase, plasma urea nitrogen, or non-esterified fatty acids, $\mathrm{e}_{\mathrm{ijkl}}$ or $\mathrm{e}_{\mathrm{ijk} \mathrm{km}}=$ residuals.

From each analysis, least squares means were generated and when significant by ANOVA, separated using the PDIFF option of SAS for main or interaction effects. Pearson correlation analysis (SAS Institute Inc.) was performed to study the relationships among selected dependent variables [29]. Significance was determined at $P<0.05$, but difference of $0.05 \leq P<0.1$ was considered as trends.

\section{Results}

\section{Body weight and animal behavior}

The mean BW of sheep $(39.6 \pm 0.47 \mathrm{~kg})$ was significantly higher than that of goats $(32.1 \pm 0.47 \mathrm{~kg})$ in this experiment
(Figure 1). Diet and FDT significantly influenced $(P<0.05)$ BW of experimental animals. The BW were $36.9 \pm 0.47$ and $34.9 \pm 0.47 \mathrm{~kg}$ in $\mathrm{CD}$ and $\mathrm{HD}$ groups, respectively. Mean BW of animals in the 12- and 24-h FDT groups were $36.8 \pm 0.47$ and $35.0 \pm 0.47 \mathrm{~kg}$, respectively. Species $\times$ diet and diet $\times$ FDT interactions also had significant effects on BW of animals during the experimental period (Figure 1).

Frequencies of standing, moving, and agonistic behaviors were higher $(P<0.05)$ in goats than sheep (Table 2$)$. Sheep spent more time lying down than goats $(P<0.01)$. Animals from the CD group had significantly higher frequencies of moving and agonistic behaviors than those from the HD group. The frequencies of standing and lying behaviors were higher in animals from the HD group than those from the CD group. Animals rarely drank water during the preslaugher holding period and thus the frequency of drinking behavior was not affected $(P>0.05)$ by either
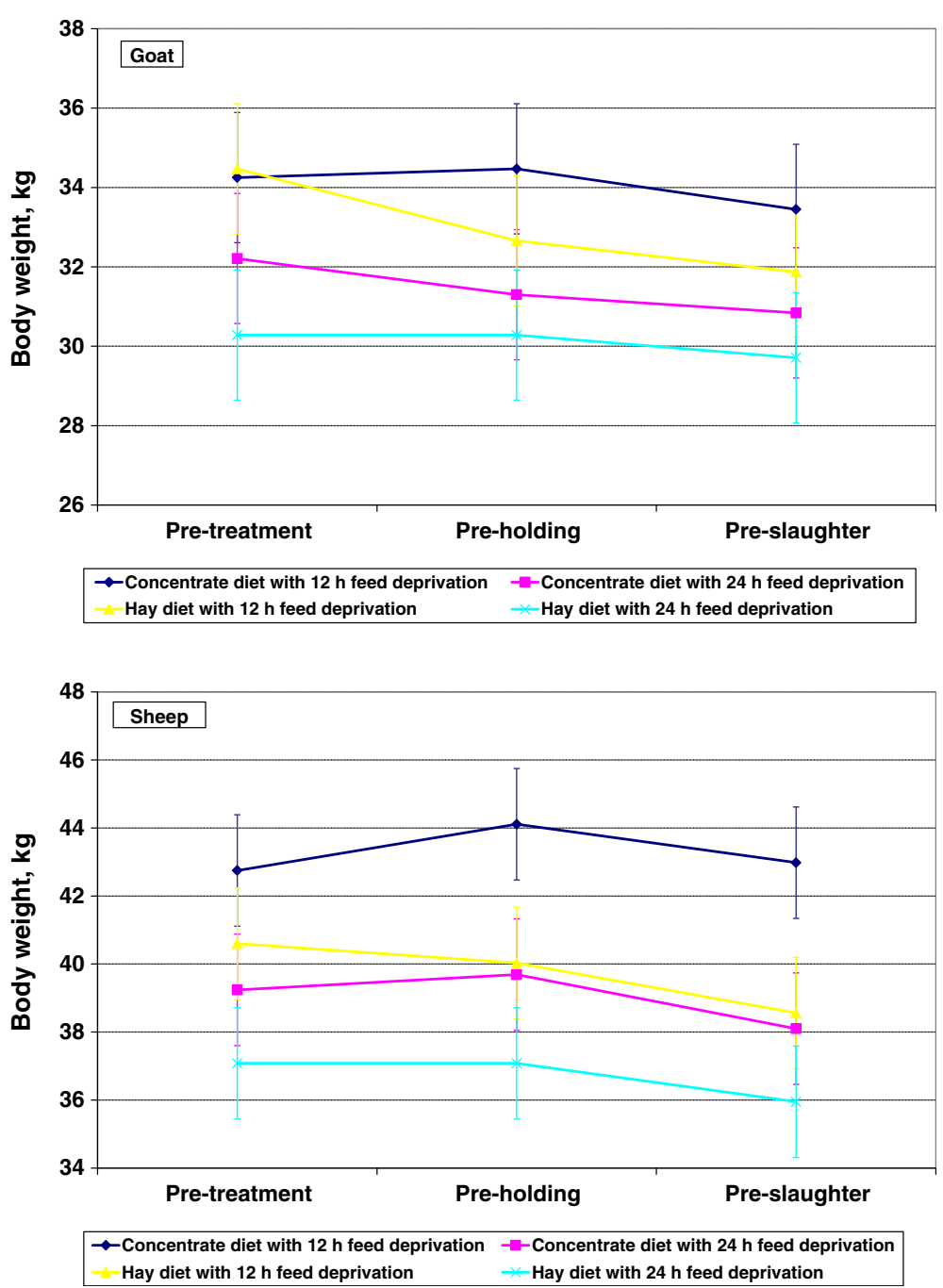

Figure 1 Body weights of sheep and goats measured prior to feeding (pre-treatment), holding (pre-holding), and slaughter (pre-slaughter). 
Table 2 Effects of species, diet, and feed deprivation time (FDT) on blood hormone, metabolite, behavior, and muscle $\mathrm{pH}$ in sheep and goats

\begin{tabular}{|c|c|c|c|c|c|c|c|c|c|c|}
\hline \multirow[b]{2}{*}{ Response } & \multicolumn{2}{|c|}{ Species } & \multirow[b]{2}{*}{$P$-value } & \multicolumn{2}{|c|}{ Diet } & \multirow[b]{2}{*}{$P$-value } & \multicolumn{2}{|c|}{ FDT } & \multirow{3}{*}{$P$-value } & \multirow{3}{*}{ SE } \\
\hline & Goat & Sheep & & HD & $C D$ & & 12-hrs & 24-hrs & & \\
\hline $\mathbf{n}$ & 16 & 16 & & 16 & 16 & & 16 & 16 & & \\
\hline \multicolumn{11}{|l|}{ Blood hormone } \\
\hline Plasma cortisol, ng/mL & 54.76 & 80.11 & 0.2027 & 62.79 & 72.08 & 0.6452 & 64.84 & 70.02 & 07911 & 13.612 \\
\hline \multicolumn{11}{|l|}{ Blood metabolite ${ }^{1}$} \\
\hline Plasma glucose, mg/dL & 130.39 & 128.54 & 0.8888 & 122.60 & 136.24 & 0.2159 & 132.37 & 126.47 & 0.5888 & 7.551 \\
\hline $\mathrm{PUN}, \mathrm{mg} / \mathrm{dL}$ & 17.24 & 18.30 & 0.6820 & 17.24 & 18.30 & 0.6468 & 17.16 & 18.38 & 0.5944 & 1.603 \\
\hline Plasma CK activity, IU & $571.74^{\mathrm{b}}$ & $863.94^{\mathrm{a}}$ & 0.0392 & 732.97 & 702.72 & 0.8265 & 747.15 & 688.54 & 0.6798 & 95.210 \\
\hline Plasma NEFA, mEq/L & $589.78^{b}$ & $1056.05^{\mathrm{a}}$ & 0.0054 & 953.56 & 692.27 & 0.1105 & 729.05 & 916.79 & 0.2108 & 105.01 \\
\hline \multicolumn{11}{|l|}{ Behavioral observations ${ }^{2}$} \\
\hline Standing & $3.49^{\mathrm{a}}$ & $3.24^{b}$ & 0.0008 & $3.46^{\mathrm{a}}$ & $3.26^{b}$ & 0.0084 & & & & \\
\hline Moving & $0.37^{\mathrm{a}}$ & $0.28^{\mathrm{b}}$ & 0.0440 & $0.19^{b}$ & $0.46^{\mathrm{a}}$ & 0.0001 & & & & \\
\hline Agonistic & $0.13^{\mathrm{a}}$ & $0.01^{b}$ & 0.0001 & $0.03^{b}$ & $0.11^{\mathrm{a}}$ & 0.0024 & & & & \\
\hline Lying & $0.00^{\mathrm{b}}$ & $0.48^{\mathrm{a}}$ & 0.0001 & $0.32^{\mathrm{a}}$ & $0.16^{\mathrm{b}}$ & 0.0043 & & & & \\
\hline Drink & 0.00 & 0.003 & 0.3176 & 0.002 & 0.00 & 0.3176 & & & & \\
\hline Dressing percent,\% & 43.02 & 42.84 & 0.7380 & 42.59 & 43.28 & 0.2049 & 42.79 & 43.07 & 0.5959 & 0.3752 \\
\hline \multicolumn{11}{|l|}{ Muscle $\mathrm{pH}^{3}$} \\
\hline Initial & 6.96 & 6.96 & 0.6000 & 6.97 & 6.91 & 0.2740 & 6.92 & 6.97 & 0.3688 & 0.039 \\
\hline Ultimate & $6.02^{\mathrm{a}}$ & $5.84^{\mathrm{b}}$ & 0.0002 & $5.98^{\mathrm{a}}$ & $5.87^{b}$ & 0.0141 & 5.92 & 5.93 & 0.8678 & 0.029 \\
\hline
\end{tabular}

$\mathrm{HD}=$ hay diet $\mathrm{CD}=$ concentrate diet

${ }^{1} \mathrm{PUN}=$ plasma urea nitrogen; $\mathrm{CK}=$ creatine kinase; NEFA = non-esterified fatty acids.

${ }^{2}$ Observed or $90 \mathrm{~min}$ before staring the slaughtering process.

${ }^{3}$ Inital $=\mathrm{pH}$ of longissimus muscle at immediately after skinning; Ultimate $=\mathrm{pH}$ of longissimus muscle at $24 \mathrm{~h}$ postmortem.

a,b Within a row, least squares means that do not have a common superscript letter differ $(P<0.05)$

species or diet. Species $\times$ diet interaction effect was significant for frequencies of standing, agonistic, and lying behaviors (Figure 2). Hay-fed goats $(3.7 \pm 0.08 / \mathrm{min})$ had a higher $(P<0.05)$ frequency of the standing behavior compared to other treatment groups (species $\times$ diet); and, concentrate-fed goats $(0.2 \pm 0.03 / \mathrm{min})$ also had a higher $(P<0.05)$ frequency of agonistic behavior compared to other groups. However, sheep $(0.6 \pm 0.06 / \mathrm{min})$ fed with the concentrate had a higher $(P<0.05)$ frequency of the lying behavior compared to other groups.

\section{Blood hormone and metabolite concentrations}

Plasma cortisol, glucose, and plasma urea nitrogen (PUN) concentrations were not influenced $(P>0.05)$ by any of the factors studied (Table 2). The interaction effects were also not significant for plasma cortisol or any of the metabolic concentrations (glucose, creatine kinase, plasma urea nitrogen, and non-esterified fatty acids). However, plasma creatine kinase $(\mathrm{CK})$ activities and non-esterified fatty acids (NEFA) levels were different $(P<0.05)$ between species (Table 2). The HD animals tended to have higher $(P=0.11)$ plasma NEFA levels than CD animals (Table 2$)$.

\section{Carcass yield and muscle pH}

Carcass yield ranged from 40 to $45 \%$ in the present experiment, but was not influenced by species, diet, or FDT (Table 2). However, goats $(43.7 \pm 0.53 \%)$ deprived of feed for 24-h had a higher mean carcass yield than those deprived for 12 -h $(42.3 \pm 0.53 \%)$, while an opposite trend was noticed in sheep (species $\times$ FDT, $P<0.05$, Figure 3).

The initial $\mathrm{pH}$ of LM was not affected $(P>0.05)$ by species, diet, or FDT (Table 2). However, species x FDT interaction effect was significant (Figure 4). Sheep subjected to 12 -h feed deprivation $(7.02 \pm 0.055)$ had lower $(P<0.05)$ $\mathrm{pH}$ values than those subjected to $24-\mathrm{h}$ feed deprivation $(6.83 \pm 0.055)$, while the initial $\mathrm{pH}$ of goat carcasses were not affected by FDT. The ultimate $\mathrm{pH}$ was higher in goats compared to sheep $(P<0.05)$ and higher in HD compared to $\mathrm{CD}$ animals $(P<0.05$, Table 2$)$. However, the interaction effects were not significant $(P>0.05)$ for the ultimate muscle $\mathrm{pH}$ values in the current study.

\section{Skin bacterial counts}

Pre-holding E. coli counts of skin samples were not influenced $(P<0.05)$ by species, diet, or diet $\times$ species interaction 


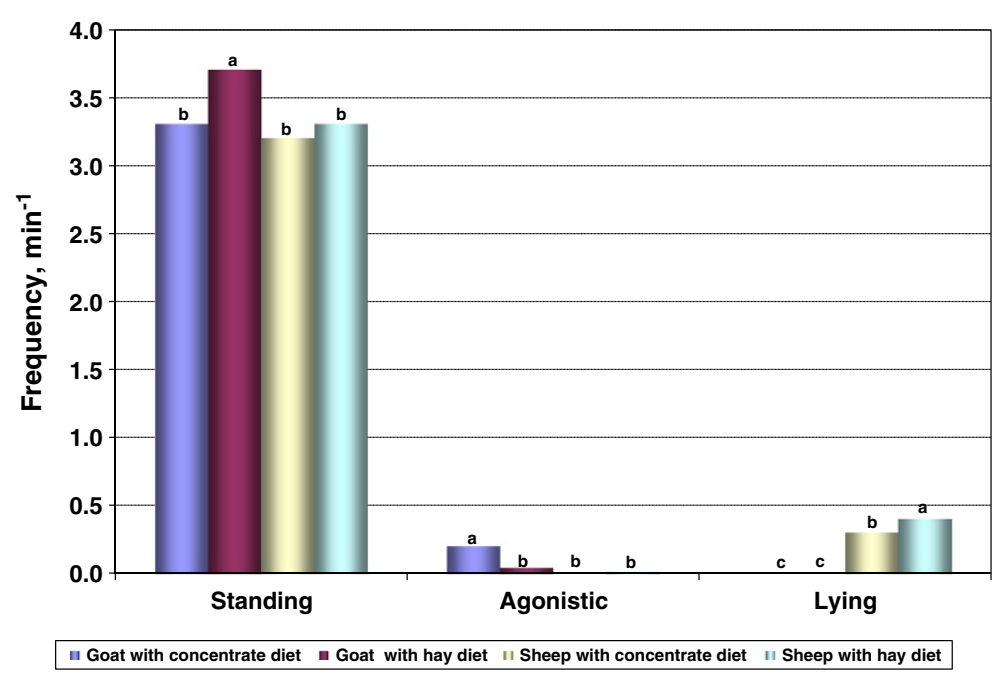

Figure 2 Effect of species and diet on standing ( $S E=0.076)$, agonistic $(S E=0.026)$, and lying $(S E=0.056)$ behaviors in the holding pens during a 90-min period prior to slaughter. For any behavior, bars bearing different letters are different $(P<0.05)$.

effects (Table 3 ). However, TCC of skin were significantly different between the two species. Goats had lower $(P<0.05)$ coliform counts in the skin than sheep (Table 3). Diet treatments or diet $\mathrm{x}$ species interaction factors had no significant effects on TCC (Table 3). The TCC was influenced $(P<0.05)$ by the species $\times$ diet $\times$ FDT interaction (Figure 5 ), with concentrate-fed sheep having the highest TCC $(P<0.05$, $3.73 \pm 0.353 \log _{10} \mathrm{CFU} / \mathrm{cm}^{2}$ ) after $12 \mathrm{~h}$ feed deprivation compared to all other groups. Goats also had lower $(P<0.05)$ skin APC compared to sheep (Table 3). No significant effects of diet and diet $\mathrm{x}$ species interaction were detected in aerobic plate counts of skin.

Preslaughter skin E. coli counts and TCC were different $(P<0.05)$ between species (Table 3$)$, and goats had lower $(P<0.05)$ counts of $E$. coli and TCC in skin swab samples compared with sheep. Diet, FDT, or interaction effects were not significant $(P>0.05)$ for skin $E$. coli and total coliform counts (Table 3 ). However, skin swab samples of the 24-h feed deprivation group tended $(P=0.12)$ to have higher $E$. coli counts than the $12 \mathrm{~h}$ group. Total coliform counts tended $(P=0.14)$ to be higher in the 24-h group than 12 -h feed deprivation group (Table 3$)$. Aerobic plate counts of skin swab samples were not influenced $(P>0.05)$ by any of the main effects or interactions.

\section{Carcass bacterial counts}

Diet, species, FDT, and their interactions had no significant effects on E. coli and coliform counts (Table 3). Aerobic plate counts of carcass swab samples were also not influenced $(P>0.05)$ by any of the treatment factors or

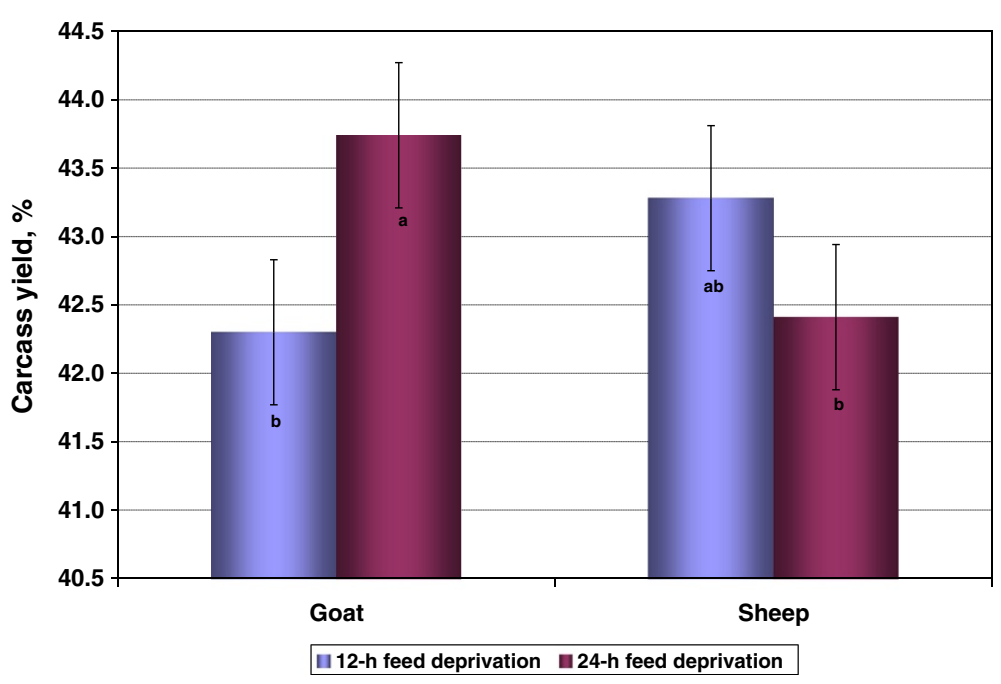

Figure 3 Effect of species and feed deprivation time on carcass yields $(\mathrm{SE}=\mathbf{0 . 5 3 1}$ ). Bars bearing different letters are different $(P<0.05)$. 


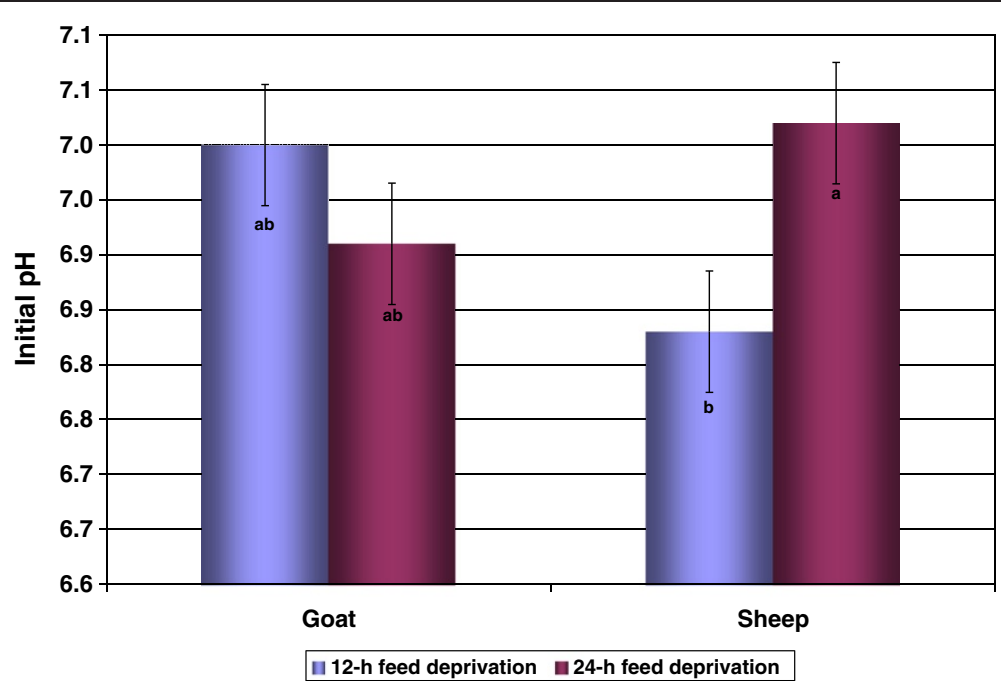

Figure 4 Effect of species and feed deprivation time on the initial $\mathrm{pH}$ of longissimus muscle $(\mathrm{SE}=\mathbf{0 . 0 5 5})$. Bars bearing different letters are different $(P<0.05)$.

their interactions, except the feed deprivation (FD) time (Table 3). Carcasses from the $12 \mathrm{~h}$ feed deprivation group had higher $(P<0.05)$ APC than those from $24 \mathrm{~h}$ group. Carcass swab samples from sheep tended $(P=0.07)$ to have higher APC than those from goats (Table 3).

\section{Discussion}

In sheep, the body weights appeared to increase due to concentrate feeding, but did not change or decrease due to hay feeding. In goats, there was no clear pattern in body weight changes due to diet. However, body weights decreased due to feed deprivation in both sheep and goats. Live weight losses during the preslaughter period are of major concern in small ruminants. Live weight shrinkage can be about $10 \%$ in goats after $18 \mathrm{~h}$ feed deprivation, and about 7\% in sheep after $24 \mathrm{~h}$ feed deprivation [12,13]. These live weight losses can be attributed to reductions in gut weights, since the

Table 3 Effects of species, diet, and feed deprivation time (FDT) on the microbial counts $\left(\log _{10} \mathrm{CFU} / \mathrm{cm}^{2}\right)$ on skin and carcass of sheep and goats

\begin{tabular}{|c|c|c|c|c|c|c|c|c|c|c|}
\hline \multirow[b]{2}{*}{ Response } & \multicolumn{2}{|c|}{ Species } & \multirow[b]{2}{*}{$P$-value } & \multicolumn{2}{|c|}{ Diet } & \multirow[b]{2}{*}{$P$-value } & \multicolumn{2}{|c|}{ FDT } & \multirow{3}{*}{$P$-value } & \multirow{3}{*}{ SE } \\
\hline & Goat & Sheep & & HD & $\mathrm{CD}$ & & 12-hrs & 24-hrs & & \\
\hline $\mathbf{n}$ & 16 & 16 & & 16 & 16 & & 16 & 16 & & \\
\hline \multicolumn{11}{|l|}{ Skin, pre-holding $^{1}$} \\
\hline E. coli count & 2.00 & 2.21 & 0.2129 & 2.06 & 2.16 & 0.5527 & & & & \\
\hline Total coliform count & $2.12^{\mathrm{b}}$ & $3.04^{\mathrm{a}}$ & 0.0011 & 2.43 & 2.73 & 0.2413 & & & & \\
\hline Aerobic plate count & $8.21^{\mathrm{b}}$ & $8.53^{\mathrm{a}}$ & 0.0305 & 8.42 & 8.31 & 0.4511 & & & & \\
\hline \multicolumn{11}{|l|}{ Skin, pre-slaughtering ${ }^{2}$} \\
\hline E. coli count & $2.23^{\mathrm{b}}$ & $2.93^{\mathrm{a}}$ & 0.0118 & 2.56 & 2.60 & 0.8650 & 2.38 & 2.78 & 0.1238 & 0.180 \\
\hline Total coliform count & $2.26^{\mathrm{b}}$ & $3.01^{\mathrm{a}}$ & 0.0135 & 2.60 & 2.67 & 0.8074 & 2.42 & 2.85 & 0.1352 & 0.197 \\
\hline Aerobic plate count & 8.31 & 8.30 & 0.8017 & 8.33 & 8.28 & 0.3198 & 8.34 & 8.28 & 0.2163 & 0.035 \\
\hline \multicolumn{11}{|l|}{ Carcass, pre-washing $^{3}$} \\
\hline E. coli count & 2.28 & 2.51 & 0.2212 & 2.34 & 2.44 & 0.6018 & 2.28 & 2.41 & 0.8959 & 0.134 \\
\hline Total coliform count & 2.29 & 2.56 & 0.1999 & 2.35 & 2.50 & 0.4587 & 2.43 & 2.43 & 1.0000 & 0.141 \\
\hline Aerobic plate count & 7.93 & 8.28 & 0.0718 & 8.16 & 8.04 & 0.5076 & $8.35^{\mathrm{a}}$ & $7.85^{b}$ & 0.0128 & 0.131 \\
\hline
\end{tabular}

$\mathrm{HD}=$ hay diet; $\mathrm{CD}=$ concentrate diet.

${ }^{1}$ Skin swabs from hind leg before depriving feed to experimental animals.

${ }^{2}$ Skin swabs from hind leg right before starting slaughtering.

${ }^{3}$ Carcass swabs from flank, brisket and leg regions right before washing after skinning and gut removed.

$\mathrm{a}, \mathrm{b}$ Within a row, least squares means that do not have a common superscript letter differ $(P<0.05)$. 


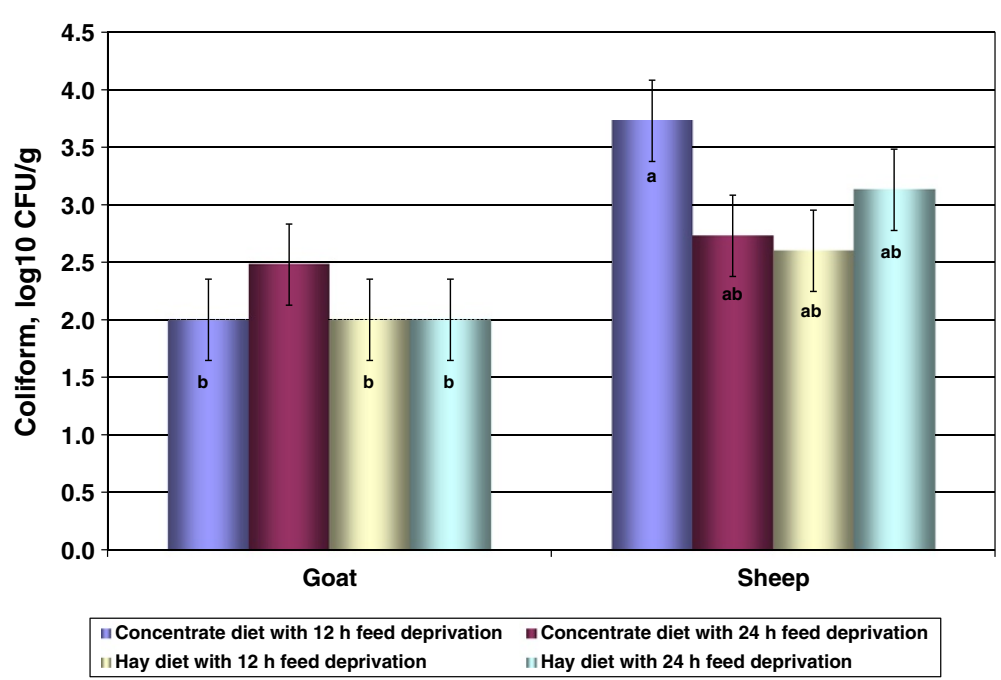

Figure 5 Effect of species, diet, and feed deprivation time on pre-holding total coliform counts of skin swab samples $(\mathrm{SE}=0.353)$. Bar bearing different letters are different $(P<0.05)$.

gastrointestinal tract contributes to a major proportion of live weight in small ruminants [30].

Plasma cortisol and certain metabolite concentrations are good indicators of the physiological status of animals as influenced by preslaughter dietary treatment and FDT. The cortisol concentrations were not influenced by species, diet, or FDT in the present experiment. Feed deprivation combined with a 2.5 -h transportation has been reported to elevate cortisol concentrations in goats [12]. Transporting animals from the experimental facility to the slaughter plant was completed within $10 \mathrm{~min}$ in the present study. It appears that feed deprivation alone for 12 or $24 \mathrm{~h}$ is not stressful enough to elevate circulating cortisol concentrations in sheep and goats. A similar effect was observed in a previous study when Spanish does were feed deprived for 7,14 , or $21 \mathrm{~h}$ [24]. However, feed deprivation has been reported to elevate cortisol concentrations in sheep [19]. Creatine kinase activities were higher in sheep compared to goats, although behavioral observations showed that goats were more active than sheep during preslaughter holding. Creatine kinase activity in blood increases due to muscle damage or increased muscular activity in animals [31]. Plasma NEFA concentrations were also higher in sheep than goats. The higher CK and NEFA levels may be attributed simply to a species difference. It is not clear if size of animals could have contributed to this effect, since the sheep used in this study were heavier than goats. Hayfed animals tended to have higher NEFA concentrations than concentrate-fed animals. Furthermore, animals subjected to $24 \mathrm{~h}$ of feed deprivation tended to have higher NEFA concentrations than those subjected to $12 \mathrm{~h}$ of feed deprivation. Knowles et al. [22] reported that the plasma NEFA concentrations increased in sheep after $24 \mathrm{~h}$ feed deprivation. Kouakou et al. [23] found that feed restriction elevated plasma NEFA concentration in goats because feed deprivation increases lipolysis in animals, which in turn increases free fatty acid levels in the blood [32].

In the present study, carcasses from $\mathrm{CD}$ group had lower ultimate LM pH values than HD animals (Table 2). Variation in glycogen content of muscles may be responsible for the differences in the ultimate $\mathrm{pH}$. Glycogen content of muscles at the time of slaughter is the important factor that affects muscle ultimate $\mathrm{pH}$ and meat quality [33]. Forage-finished animals have been reported to produce lower quality meat than grain-finished animals $[34,35]$. Immonem et al. [36] reported variations in the ultimate $\mathrm{pH}$ of muscle due to energy levels in the diet of cattle, and they found that cattle fed a high energy diet had a lower $(P<0.05)$ ultimate muscle $\mathrm{pH}(5.69 \pm 0.03)$ value compared to cattle fed a low energy diet $(5.93 \pm 0.03)$. In contrast, Diaz et al. [37] did not find any significant differences in meat quality and muscle $\mathrm{pH}$ (measured immediately after slaughter, after $45 \mathrm{~min}$ and after $24 \mathrm{~h}$ ) from pasture-fed and concentrate-fed lambs.

The skin of a live animal becomes contaminated with microorganisms derived from a wide range of sources such as feces, soil, water and vegetation [2]. The APC, TCC, and E. coli counts of skin swab samples collected at two different times in the present study was not influenced by diet. Skin swab samples collected from sheep showed higher bacterial counts than goats. Sheep fleece may be responsible for picking up fecal material from the pen floor and retaining the contamination for longer time. Behavioral observations of the animals during holding period revealed that sheep tended to spend more time lying down in the pens than goats. It is possible that goats were not able to withstand the cold temperature of concrete floors, which would have 
prevented them from lying down. This experiment was conducted in the month of December. Skin swab samples collected from the 24-h feed deprivation group showed higher E. coli counts than the 12-h group. There is always more chance for skin contamination with fecal material if the animals spend more time in the holding pens.

Preslaughter diet and feed deprivation time had no effect on TCC and E. coli counts of carcass swab samples. Major sources of carcass contamination are unclean animal skin and viscera of animals entering the slaughter facility [1]. Carcass TCC and E. coli counts were not correlated with skin counts. Elder et al. [38] found no correlation between the prevalence of E. coli O157 contamination on cattle hides and that resulting on carcasses. In their study, the prevalence of $E$. coli $\mathrm{O} 157$ on the carcasses was higher than that on hides.

\section{Conclusions}

Preslaughter diet and FDT did not influence the physiological status of sheep and goats according to plasma cortisol, glucose, CK, PUN, and NEFA. Feed deprivation may significantly decrease body weights in sheep and goats. Sheep had higher skin contamination than goats, probably due to differences in their behavior during preslaughter holding. Sheep spent more time lying down than goats in holding pens. Diet and FDT did not influence skin contamination in sheep and goats. There was no relationship between skin contamination and carcass contamination in the present study. Preslaughter diet may have an effect on the energy reserves in muscles, as the LM ultimate $\mathrm{pH}$ was lower in the concentrate-fed group. The results indicate that diet can be manipulated without significant effects on physiological responses in sheep and goats.

\section{Competing interests}

The authors declare that they have no competing interests.

\section{Authors' contributions}

All authors made significant contributions to design and perform the research. Especially GK and VRG conducted all data analyses and drafted the initial manuscript. All authors read and agreed the final manuscript.

\section{Acknowledgments}

The authors would like to thank Dr. Isabel Blackman for advice with microbiological analysis and Krishna Gadiyaram, Shirely Wang, and Nealie Moye for technical assistance.

Received: 5 May 2014 Accepted: 18 August 2014

Published: 28 August 2014

\section{References}

1. Grau FH: Prevention of microbial contamination in the export beef abattoir. In Elimination of Pathogenic Organisms from Meat and Poultry. Edited by Smulders FJM. Amsterdam: Elsevier; 1987:221-234.

2. McEvoy JM, Doherty AM, Finnerty M, Sheridan JJ, McGuire L, Blair IS, MacDowell DA, Harrington D: The relationship between hide cleanliness and bacterial numbers on beef carcasses at a commercial abattoir. Lett Appl Microbiol 2000, 30:390.
3. Reid CA, Small A, Avery S, Bunic S: Presence of food-borne pathogens on cattle hides. Food Control 2002, 13:411-415.

4. Kudva IT, Hunt CW, Williams CJ, Nance UM, Hovde CJ: Evaluation of dietary influences on Escherichia coli 0157:H7 shedding by sheep. Appl Environ Microbiol 1997, 63:3878-3886.

5. Reid CA, Avery SM, Warriss PD, Buncic S: The effect of feed withdrawal on Escherichia coli shedding in beef cattle. Food Control 2002, 13:393-398.

6. Callaway TR, Anderson RC, Edrington TS, Elder RO, Genovese KJ, Bischoff KM, Poole TL, Jung YS, Harvey RB, Nisbe DJ: Preslaughter intervention strategies to reduce food-borne pathogens in food animals. J Anim Sci 2002, 81(E. Suppl. 2):E17-E23.

7. Jacobson HL, Tanya AN, Gregory NG, Bell RG, Roux GL, Haines JM: Effect of feeding pasture-finished cattle different conserved forages on Escherichia coli in the rumen and feces. Meat Sci 2002, 2002(62):93-106.

8. Byers FM, Schelling GT: Microbiology of the rumen and intestine. In The Ruminant Animal Digestive Physiology and Nutrition. Edited by Church DC. NJ: Prentice Hall; 1988:125-171.

9. Allison MJ, Robinson IM, Dougherty RW, Bucklin JA: Grain overload in cattle and sheep: changes in microbial population in the cecum and rumen. Amer J Vet Res 1975, 36:181-185.

10. Gregory NG: Animal Welfare and Meat Science. NY, USA: CABI Pub; 1998.

11. Callaway TR, Anderson RC, Edrington TS, Elder RO, Genovese KJ, Bischoff KM, Poole TL, Jung YS, Harvey RB, Nisbet DJ: Preslaughter intervention strategies to reduce food-borne pathogens in food animals. J Anim Sci 2003, 81(E. Suppl. 2):E17-E23.

12. Kannan G, Terrill TH, Kouakou B, Gazal OS, Gelaye S, Amoah EA, Samake S: Transportation of goats: Effect on physiological stress response and live weight loss. J Anim Sci 2000, 78:1450-1457.

13. Kirton AH, Moss RA, Talyor AG: Weight losses from milk and weaned lamb in mid Canterbury resulting from different lengths of starvation before slaughter. N Z J Agric Res 1971, 14:149-160.

14. Chillard Y, Doreau M, Bocquier F, Lobley GE: Digestive and metabolic adaptations of ruminants to variations in food supply. In Recent Developments in the Nutrition of Herbivores. Edited by Journet M, Grenet $E_{\text {, }}$ Farce MH, Theriez M, Demarquilly C. France: INRA Editions; 1995.

15. Silva JA, Patarata $\mathrm{L}$, Martins $\mathrm{C}$ : Influence of ultimate $\mathrm{pH}$ on bovine meat tenderness during ageing. Meat Sci 1993, 52:453-459.

16. Lawrie RA: Metabolic stresses which affect muscle. In The Physiology and Biochemistry of Muscle as Food. Edited by Cassens EJ, Briskey RG, Trautman JC. Madison: The University of Wisconsin Press; 1996:137-164.

17. Braggins TJ: Effect of stress-related changes in sheep meat ultimate $\mathrm{pH}$ on cooked odor and flavor. J Agri Food Chem 1996, 44:2352-2360.

18. Warriss PD: Antemorterm factors influencing the yield and quality of meat from farm animals. In Quality and Grading of Carcasses of Meat Animals. Edited by Morgan Jones SD. New York: CRC Press; 1995:1-15.

19. Murayama S, Moriya K, Saaki Y: Changing pattern of plasma cortisol level associated with feeding in sheep. Jpn J Zootech Sci 1986, 57:317-323.

20. Shorthose WR, Wythes JR: Transport of sheep and cattle. In 34th Int. Cong Meat Sci. Technol., Part A. Brisbane, Australia; 1988.

21. Schaefer $A L$, Jones SDM, Stanley RW: The use of electrolyte solutions for reducing transport stress. J Anim Sci 1997, 75:258-265.

22. Knowles TG: A review of the road transport of cattle. Vet Rec 1999, 144:197-201.

23. Kouakou B, Gazal OS, Terrill TH, Kannan G, Galaye S, Amoah EA: Effects of plane of nutrition on blood metabolites and hormone concentration in goats [abstract]. J Anim Sci 1999, 77(Suppl.1):267.

24. Kannan G, Terrill TH, Kouakou B, Gelaye S, Amoah EA: Simulated preslaughter holding and isolation effects on stress responses and live weight shrinkage in meat goats. J Anim Sci 2002, 80:1771-1780.

25. Barroso FG, Alados CL, Boza J: Social hierarchy in the domestic goat: effect on food habits and production. Appl Anim Behav Sci 2000, 69:35-53.

26. Kannan G, Jenkins AK, Eega KR, Kouakou B, McCommon GW: Preslaugher spray-washing effects on physiological stress responses and skin and carcarss microbial counts in goat. Small Rumin Res 2007, 67:14-19.

27. FSIS-USDA: Pathogen reduction: hazard analysis and critical control point (HACCP) systems, final rule. Fed Reg 1996, 61:38805-38989.

28. The $3 \mathrm{M}$ Products: Manufacture's Interpretation Guide. MN: The $3 \mathrm{M}$ Microbiology Products; 1999.

29. Steel RGD, Torrie JH, Dickey DA: Principles and Procedures of Statistics: A Biometrical Approach. 3rd edition. New York: McGraw-Hill Book Co.; 1996.

30. Romans JR, Costello WJ, Carlson CW, Greaser ML, Jones KW: The Meat We Eat. 13th edition. IL: Interstate publishers; 1994 
31. Wilson BW, Nieberg PS, Buhr RJ, Kelly BJ, Shultz FT: Turkey muscle growth and focal myopathy. Poult Sci 1990, 69:1553-1562.

32. Warriss PD, Bevis EA, Brown SN, Ashby JG: An examination of potential indices of fasting time in commercially slaughtered sheep. Br Vet J 1989 145:242-248.

33. Bidner TD, Schupp AR, Montgomery RE, Carpenter JC Jr: Acceptability of beef finished on all-forage, forage plus-grain or high energy diets. J Anim Sci 1981, 53:1181-1187.

34. Bowling RA, Smith GC, Carpenter ZL, Dutson TR, Oliver WM: Comparison of forage-finished and grain-finished beef carcasses. J Anim Sci 1977 45:209-215.

35. Melton SL, Amiri M, Davis GW, Backus WR: Flavor and chemical characteristics of ground beef from grass-, forage-grain- and grain-finished steers. J Anim Sci 1982, 55:77-87.

36. Immonem K, Puolanne E, Hissa K, Ruusunen M: Bovine muscle glycogen concentration in relation to finishing diet, slaughter and ultimate $\mathrm{pH}$. Meat Sci 2000, 55:25-31.

37. Diaz MT, Velasco S, Caneque V, Lauzurica S, Ruiz de Huidoro F, Perez C, Gonzalez J, Manzanares C: Use of concentrate or pasture for fattening lambs and its effect on carcass and meat quality. Small Rumin Res 2002, 43:257-268.

38. Elder RO, Keen JE, Siragusa GR, Barkocy-Gallagher GA, Koohmaraie M, Laegreid WW: Correlation of enterohemorrhagic Escherichia coli 0157 prevalence in feces, hides, and carcasses of beef cattle during processing. Proc Natl Acad Sci 2000, 97:2999-3003

doi:10.1186/2049-1891-5-42

Cite this article as: Kannan et al.: Preslaughter diet management in sheep and goats: effects on physiological responses and microbial loads on skin and carcass. Journal of Animal Science and Biotechnology

2014 5:42.

\section{Submit your next manuscript to BioMed Central and take full advantage of:}

- Convenient online submission

- Thorough peer review

- No space constraints or color figure charges

- Immediate publication on acceptance

- Inclusion in PubMed, CAS, Scopus and Google Scholar

- Research which is freely available for redistribution 